\title{
Cross-sectional study of risk factors for atherosclerosis in the Azorean population
}

\author{
Teresa Cymbron 1,2,3, Mafalda Raposo ${ }^{1,2,3}$, Nadiya Kazachkova ${ }^{1,2,3}$, Conceição Bettencourt ${ }^{1,2,3,4}$, \\ Francisca Silva ${ }^{1,2,3}$, Cristina Santos ${ }^{5}$, Yahya Dahmani ${ }^{6}$, Paula Lourenço ${ }^{3,7}$, Rita Ferin ${ }^{1,8}$, \\ Maria Leonor Pavão ${ }^{1,8}$ \& Manuela Lima ${ }^{1,2,3}$
}

${ }^{1}$ Center of Research in Natural Resources (CIRN), '2Department of Biology, University of the Azores, Ponta Delgada, Portugal, ${ }^{3}$ Molecular and Cellular Biology Institute (IBMC), University of Porto, Porto, Portugal, ${ }^{4}$ Lab. de Diagnostico Molecular del Banco de Tejidos para Investigaciones Neurológicas (BTIN), Facultad de Medicina, Universidad Complutense de Madrid, Madrid, Spain, ${ }^{5}$ Unitat Antropologia Biològica, Dep. Biologia Animal, Biologia Vegetal i Ecologia, Universitat Autònoma de Barcelona, Bellaterra (Barcelona), Spain, ${ }^{6}$ Department of Biochemistry, Molecular and Cellular Biology, Miguel Servet 177, University of Zaragoza, 50013 Zaragoza, Spain, 'Specialized Service of Epidemiology and Molecular Biology (SEEBMO), Hospital of Santo Espírito, Angra do Heroísmo, and ${ }^{8}$ Department Technological Sciences and Development, University of the Azores, Ponta Delgada, Portugal

Background: Atherosclerosis-a major cause of vascular disease, including ischemic heart disease (IHD), is a pathology that has a two-fold higher mortality rate in the Azorean Islands compared to mainland Portugal.

Aim: This cross-sectional study investigated the role of genetic variation in the prevalence of atherosclerosis in this population.

Subjects and methods: A total of 305 individuals were characterized for polymorphisms in eight susceptibility genes for atherosclerosis: ACE, PAI1, NOS3, LTA, FGB, ITGB3, PON1 and $A P O E$. Data were analysed with respect to phenotypic characteristics such as blood pressure, lipid profile, life-style risk factors and familial history of myocardial infarction. Results: In the total sample, frequencies for hypercholestrolemic, hypertensive and obese individuals were $63.6 \%, 39.3 \%$ and $23.3 \%$, respectively. The genetic profile was similar to that observed in other European populations, namely in mainland Portugal. No over-representation of risk alleles was evidenced in this sample.

Conclusions: One has to consider the possibility of an important non-genetic influence on the high cholesterolemia present in the Azorean population. Since diet is the most important life-style risk factor for dyslipidemia, studies aiming to evaluate the dietary characteristics of this population and its impact on serum lipid levels will be of major importance.

Keywords: Polymorphisms, susceptibility genes, atherosclerosis, ischemic heart disease, Azores

\section{INTRODUCTION}

Atherosclerosis (AT), the major cause of cardiovascular disease, including Ischemic Heart Disease (IHD), is a multifactoral pathological process where inflammation and oxidative processes are key components from fatty streak formation to plaque rupture and thrombosis (Roy et al. 2009). The death rate due to IHD is about twice as high in the Azores Archipelago as in mainland Portugal (DirecçãoGeral da Saúde 2009). However, the extent of the contribution of genetic risk factors to this prevalence remains unstudied. We developed a cross-sectional study of risk factors for AT, including characterization of the polymorphisms in a series of established susceptibility genes for AT, namely ACE-angiotensin converting enzyme (Rigat et al. 1990; Samani et al. 1996; Sabbagh et al. 2007), PAI1-plasminogen activator inhibitor 1 (Onalan et al. 2008), NOS3 - nitric oxide synthase (Casas et al. 2004), LTA-lymphotoxin $\alpha$ (Schreyer et al. 2002; Trompet et al. 2008), FGB-fibrinogen $\beta$ (Renner et al. 2002; Gialeraki et al. 2008), ITGB3-integrin $\beta$-3 (Marian et al. 1996; Ridker et al. 1997; Knowles et al. 2007), PON1paraoxonase 1 (Mackness et al. 1998; Salonen et al. 1999; Garcés et al. 2008) and APOE-apolipoprotein E (Burman et al. 2009).

These genes are mainly involved in physiological processes which have been shown to be related to endothelial dysfunction (NOS3), inflammation (LTA), dyslipidemia (APOE and PON1), dysfunctional coagulation

Correspondence: Teresa Cymbron, Department of Biology/CIRN, University of the Azores, Rua da Mãe de Deus, Apartado 1422, 9501-801 Ponta Delgada, Azores, Portugal. Tel: + 351 296650477. Fax: + 351 296650100. E-mail: tcymbron@uac.pt

(Received 29 October 2010; accepted 4 January 2011) 
and fibrinolysis (PAI1, FGB and ITGB3), as well as blood pressure deregulation (ACE and NOS3), all of which can ultimately be involved in the atherogenic process (Roy et al. 2009).

The Azores Archipelago (Portugal) is a group of nine islands, with an area of $2344 \mathrm{Km}^{2}$ and a total population of 237315 (INE 2006). According to historical records, these islands were uninhabited until the 15th century, when the first settlers arrived, mostly from mainland Portugal and the island of Madeira. However, people of different origins, such as Spanish, French, Italian, English, German and Flemish were also among the early settlers (Matos 1989; Mendonça 1996). There is clear evidence that Jews also contributed to the peopling of the archipelago and the presence of African and Moorish slaves in the islands is also documented (Matos 1989; Mendonça 1996). Research conducted in the Azorean populations, using various types of genetic system, has shown considerable levels of diversity (Santos et al. 2003; 2009; Montiel et al. 2005); given the particular characteristics of the population size and composition of the Azores, genetic studies have been conducted for several diseases (see, for example, Bruges-Armas et al. 2002; Lima et al. 2005).

To gain insights into the determinants of atherosclerosis in the Azorean population we analysed variation in the previously listed loci, in a large sample of individuals of Azorean background and related it to specific phenotypic characteristics, such as blood pressure and serum lipid profile. Furthermore, other individual and life-style derived risk factors for AT were also analysed.

\section{MATERIALS AND METHODS}

\section{Sampling}

After informed consent, a total of 305 apparently healthy unrelated individuals were sampled by collecting peripheral blood and buccal swabs. Individuals filled in a genealogical questionnaire, which confirmed their Azorean ancestry. The samples were from the islands of São Miguel $(n=224)$, Graciosa $(n=64)$ and Flores $(n=17)$.

For all participants, data concerning age, gender, height, weight, systolic and diastolic blood pressure (BP) were registered. Body mass index (BMI) was calculated. Individuals were considered hypertensive if they presented an average systolic BP of $\geq 140 \mathrm{~mm} \mathrm{Hg}$ and/or diastolic BP of $\geq 90 \mathrm{~mm} \mathrm{Hg}$ (Chobanian et al. 2003) and/or if they were taking anti-hypertensive medication. Serum total cholesterol (TC), HDL cholesterol (HDL-C) and triglycerides (TG) were determined by collaborating laboratories, using standardized protocols. LDL cholesterol (LDL-C) concentration was calculated by the Friedewald formula (Friedewald et al. 1972). Individuals were considered hypercholesterolemic if presenting at least one of the following situations: (a) total fasting cholesterol concentration of $\geq 200 \mathrm{mg} / \mathrm{dl}$; (b) LDL-C concentration of $\geq 130$ $\mathrm{mg} / \mathrm{dl}$ and (c) use of cholesterol-lowering medication. Individuals were hypertriglyceridemic if triglycerides levels were $\geq 150 \mathrm{mg} / \mathrm{dl}$ and/or if they were being medicated for this alteration (Expert Panel on Detection, Evaluation, and
Treatment of High Blood Cholesterol in Adults 2001). Information was collected on life-style habits such as smoking. Subjects were considered smokers if they smoked or had stopped smoking in the last year. The presence of family history of myocardial infarction was considered whenever at least one-first-degree relative had a myocardial infarction.

\section{Genotyping}

DNA was extracted from buccal swabs using JETQUICK Tissue DNA SPIN Kit and from blood samples using JETQUICK Blood \& Cell Culture DNA SPIN Kit, for Genomic DNA (GENOMED), according to the manufacturer's specifications. Samples were genotyped by the Spanish National Genotyping Centre (CeGen) for seven polymorphic positions at the following candidate genes for AT: ACE (rs1799752), PAI1 (rs1799889), NOS3 (rs1799983), LTA (rs1041981), FGB (rs1800790) and ITGB3 (rs5918). Polymorphisms at the PON1 (rs854560) and APOE (rs429358; rs7412) loci were genotyped by PCR-RFLP, at CIRN's laboratories (University of the Azores), in accordance with Zhang et al. (2006) and Bettencourt et al. (2006), respectively.

\section{Statistical analysis}

Allele and genotype frequencies were estimated for all loci. Hardy-Weinberg equilibrium (HWE) was tested using an exact test, based on a Markov chain approach. An unbiased estimate of heterozygosity was computed according to Nei (1978). The statistical significance of the variance components of the AMOVA (considering the island as the main group) and the paired comparisons were determined by non-parametric procedures. Pairwise population differentiation exact tests, using allele frequencies, were carried out to compare the data obtained for the three islands. Allele frequencies for the total sample $(n=305)$ were compared with the available data for other European and nonEuropean populations. Data from mainland Portugal were taken from David et al. (2004), Ferrer-Antunes et al. (1998), Magro et al. (2003), Medeiros et al. (2002), Mendonça et al. (2008) and Rodrigues et al. (2005). For the remaining populations the data used in the differentiation tests were taken from the ALlele FREquency Database (http://alfred. med.yale.edu/alfred), SNPedia (http://www.snpedia.com), Entrez SNP database (http://www.ncbi.nlm.nih.gov/SNP). All population analyses were performed using Arlequin software version 3.0 (Excoffier et al. 2005).

A one-way between-groups multivariate analysis of covariance was conducted to compare lipid profile in accordance with APOE and PON1 55 genotypes with $p$-values adjusted for age (42.6), gender and BMI (27.4). To relate lipid profile with $A P O E$ genotype the sample was reduced to 262 individuals, since those taking lipid lowering medication were excluded from this analysis; genotypes $\varepsilon 2^{\star} \varepsilon 4(n=7)$ and $\varepsilon 4^{\star} \varepsilon 4(n=1)$ were also excluded due to the small group size. Analysis for PON1 55 vs lipid profile included a sample of 269 subjects, since individuals taking medication for dyslipidemia were excluded. Statistical 
analyses were conducted using SPSS 15.0 software (SPSS Inc., Chicago, IL). Due to the abnormal distribution of blood pressure values, a kernel non-parametric regression test was performed using the software XLSTAT version 2010 (Addinsoft 2010) to estimate the conditional expectation of ACE/NOS3 genotype vs systolic and diastolic blood pressure, using additional parameters (sex, age, BMI, smoking status, myocardial infarction status, levels of TC, LDL-C, HDL-C, TG $(\mathrm{mg} / \mathrm{dL})$. Individuals taking antihypertensive medication were excluded from the previous analysis.

In all of the analyses a $p$-value lower than 0.05 was considered statistically significant.

\section{RESULTS}

\section{Individual and life-style risk factors of AT}

One hundred and sixty-seven of the 305 samples genotyped in this study related to women $(54.7 \%)$ and 138 to men (45.3\%), with a mean age of $44 \pm 11$ years. The distribution of risk factors for the studied Azorean sample, stratified by gender and age, is shown in Table I. The total hypertensive individuals in the Azorean sample is $39.3 \%$ and the mean values for blood pressure are $129 \pm 25 \mathrm{~mm} \mathrm{Hg}$ for systolic $\mathrm{BP}$ and $78 \pm 25 \mathrm{~mm} \mathrm{Hg}$ for diastolic BP. Hypertension frequency displays a similar distribution between men and women $(26.0 \%$ and $20.0 \%$ for men and women, respectively), in the first age group ( $\leq 44$ years). In the older age group ( $>44$ years), the percentage of men with

Table I. Characterization of the Azorean population in study for several atherosclerosis risk factors.

\begin{tabular}{|c|c|c|c|c|c|}
\hline & \multicolumn{2}{|c|}{$\leq 44$ years } & \multicolumn{2}{|c|}{+45 years } \\
\hline & & \multirow{2}{*}{$\begin{array}{c}\stackrel{\bigcirc}{+} \\
(n=85) \\
\%\end{array}$} & \multirow{2}{*}{$\begin{array}{c}\sigma^{7} \\
(n=73) \\
\%\end{array}$} & \multirow{2}{*}{$\begin{array}{c}q \\
q \\
=82) \\
\%\end{array}$} & \multirow{2}{*}{$\begin{array}{c}\sigma^{\top} \\
n=65) \\
\%\end{array}$} \\
\hline & & & & & \\
\hline \multicolumn{6}{|l|}{ Hypertension } \\
\hline \multicolumn{2}{|l|}{ No } & 80.0 & 68.5 & 39.0 & 43.1 \\
\hline \multicolumn{2}{|c|}{ Yes } & 20.0 & 26.0 & 59.8 & 53.8 \\
\hline \multicolumn{2}{|c|}{ Not determined } & 0 & 5.5 & 1.2 & 3.1 \\
\hline \multicolumn{6}{|c|}{ Hypercholesterolemia } \\
\hline \multicolumn{2}{|c|}{ No } & 50.6 & 47.9 & 23.2 & 21.5 \\
\hline \multicolumn{2}{|c|}{ Yes } & 49.4 & 52.1 & 76.8 & 78.5 \\
\hline \multicolumn{6}{|c|}{ Hypertriglyceridemia } \\
\hline \multicolumn{2}{|c|}{ No } & 77.7 & 68.5 & 69.5 & 63.1 \\
\hline \multicolumn{2}{|l|}{ Yes } & 22.3 & 31.5 & 30.5 & 36.9 \\
\hline \multicolumn{6}{|l|}{$B M I$} \\
\hline$<18.5$ & Underweight & 2.4 & 0 & 0 & 0 \\
\hline $18.5-24.9$ & Normal & 43.5 & 41.0 & 17.0 & 18.5 \\
\hline $25.0-29.9$ & Overweight & 30.6 & 35.6 & 37.8 & 58.5 \\
\hline $30.0-34.9$ & Obese & 16.5 & 22.0 & 29.3 & 20.0 \\
\hline $35.0-39.9$ & Severely obese & 5.8 & 1.4 & 12.2 & 3.0 \\
\hline$>40$ & Morbidly obese & 1.2 & 0 & 3.7 & 0 \\
\hline \multicolumn{6}{|l|}{ Smoking } \\
\hline \multicolumn{2}{|l|}{ No } & 83.5 & 63.0 & 94.0 & 66.2 \\
\hline \multicolumn{2}{|l|}{ Yes } & 15.3 & 31.5 & 3.6 & 30.7 \\
\hline \multicolumn{2}{|c|}{ Not determined } & 1.2 & 5.5 & 2.4 & 3.1 \\
\hline \multicolumn{6}{|c|}{ Family history of infarction } \\
\hline \multicolumn{2}{|c|}{ No } & 56.5 & 65.7 & 51.2 & 67.7 \\
\hline \multicolumn{2}{|l|}{ Yes } & 34.1 & 23.3 & 39.0 & 27.7 \\
\hline \multicolumn{2}{|l|}{ Did not know } & 9.4 & 11.0 & 9.8 & 4.6 \\
\hline
\end{tabular}

(C) Informa UK, Ltd. hypertension doubles $(53.8 \%)$ and that of women triples $(59.8 \%)$, maintaining the similar differences between genders. The total hypercholestrolemic individuals in this sample is $63.6 \%$, the mean value of TC being $208 \pm 50$ $\mathrm{mg} / \mathrm{dL}$ and the mean value for LDL-C being $127 \pm 35$ $\mathrm{mg} / \mathrm{dL}$. In the first age group ( $\leq 44$ years), approximately half the population ( $49.4 \%$ women and $52.1 \%$ men) is hypercholesterolemic, these values rise with age, reaching in the $>44$ years old group $76.8 \%$ for women and $78.5 \%$ for men.

The individuals with hypertriglyceridemia represent $\sim$ $30 \%$ of this population, for both gender and age groups; mean TG value is $119 \pm 66 \mathrm{mg} / \mathrm{dL}$.

The total individuals with obesity are $23.3 \%$ for this population and the average value of BMI is $27 \pm 5$. Neither underweight nor morbidly obese individuals are present in men. The percentage of individuals with normal weight decreases with age in both genders; furthermore, the amount of overweight men increases by 1.6-fold (becoming $58.5 \%$ ). In the first age group ( $\leq 44$ years), obesity presents very similar values for men and women $(23.4 \%$ and $23.1 \%$ for men and women, respectively). Age has a strong impact on obesity frequency in women, almost doubling its value (45.2\%); men maintain a similar value $(23 \%)$. Concerning smoking habits, in the $\leq 44$ age group twice as many men, compared to women, were smokers $(31.5 \%$ and $15.3 \%$ of smokers, respectively). Age stratification shows no impact on the smoking habits of men, but is substantial in women at age $>44$ years, decreasing by $76 \%$. Family history of infarction presented similar values for both genders and age groups.

\section{Population analysis of AT susceptibility loci}

Since no differences were detected between samples from the three islands, we pooled the data and used it as a single Azorean sample. Corroborating the results from the differentiation tests, AMOVA showed that genetic variation within populations was significantly higher than that observed among populations $(99.7 \%$ and $0.3 \%$, respectively), providing no evidence of significant genetic differences between the islands. Allele and genotype frequencies for all analysed markers are presented in Table II. All loci were in conformity with Hardy-Weinberg equilibrium expectations. The levels of expected heterozygosity are similar to those reported for other European populations, with the highest value being registered for PAI1 (51.52\%) and the lowest for APOE (22.10\%).

When comparing the allele frequencies obtained for the present sample with those available for mainland Portugal samples (relative to loci ACE, PAI1, NOS3, FGB, PON1 and $A P O E)$ no significant differences were observed. For the analysed polymorphism at the PON1, although the most frequent allele in the Azorean sample is the $55-\mathrm{M}$ allele as opposed to mainland Portugal, where the $55-\mathrm{L}$ allele is the most frequent, the differentiation test between the populations for this locus did not reach statistical significance $(p=0.116)$. 
Table II. Allele and genotype frequencies of the polymorphisms for the seven genes for atherosclerosis among 305 Azorean.

\begin{tabular}{|c|c|c|c|c|c|}
\hline$\underline{\text { Risk factors }}$ & Position & Allele & $\%$ & Genotype & $\%$ \\
\hline \multirow[t]{3}{*}{$A C E$} & intron 16 & $\mathrm{D}$ & 61.5 & DD & $39 .($ \\
\hline & & I & 38.5 & DI & 44.9 \\
\hline & & & & II & 16.1 \\
\hline \multirow[t]{3}{*}{ PAI1 } & -675 & $5 \mathrm{G}$ & 49.2 & $5 \mathrm{G} / 5 \mathrm{G}$ & 21. \\
\hline & $4 \mathrm{G}>5 \mathrm{G}$ & $4 \mathrm{G}$ & 50.8 & $5 \mathrm{G} / 4 \mathrm{G}$ & 56. \\
\hline & & & & $4 \mathrm{G} / 4 \mathrm{G}$ & 22 \\
\hline \multirow[t]{3}{*}{ NOS3 } & $894 \mathrm{G}>\mathrm{T}$ & G & 60.0 & GG & 35 \\
\hline & & $\mathrm{T}$ & 40.0 & GT & 49 \\
\hline & & & & TT & 15. \\
\hline \multirow[t]{3}{*}{ LTA } & $804 \mathrm{C}>\mathrm{A}$ & C & 73.4 & $\mathrm{CC}$ & 54. \\
\hline & & A & 26.6 & CA & 37. \\
\hline & & & & $\mathrm{AA}$ & \\
\hline \multirow[t]{3}{*}{$F B G$} & $-455 G>A$ & G & 79.0 & GG & 61.0 \\
\hline & & A & 21.0 & GA & $36 .($ \\
\hline & & & & $\mathrm{AA}$ & \\
\hline \multirow[t]{3}{*}{ ITGB3 } & $176 \mathrm{~T}>\mathrm{C}$ & $\mathrm{T}$ & 79.7 & TT & 63.5 \\
\hline & & C & 20.3 & TC & 31.5 \\
\hline & & & & CC & 4 \\
\hline \multirow[t]{3}{*}{ PON1 } & $55 \mathrm{~L}>\mathrm{M}$ & $\mathrm{L}$ & 46.2 & LL & 16.7 \\
\hline & & M & 53.8 & ML & $59 .($ \\
\hline & & & & $\mathrm{MM}$ & 24 \\
\hline \multirow[t]{6}{*}{$A P O E$} & $471 \mathrm{~T}>\mathrm{C}$ & $\varepsilon 2$ & 7.0 & $\varepsilon 2 \star \varepsilon 2$ & \\
\hline & $609 \mathrm{C}>\mathrm{T}$ & $\varepsilon 3$ & 83.0 & $\varepsilon 2^{\star} \varepsilon 3$ & 11.8 \\
\hline & & $\varepsilon 4$ & 10.0 & $\varepsilon 2^{\star} \varepsilon 4$ & 2 \\
\hline & & & & $\varepsilon 3^{\star} \varepsilon 3$ & 68 \\
\hline & & & & $\varepsilon 3^{\star} \varepsilon 4$ & 17.1 \\
\hline & & & & $\varepsilon 4^{\star} \varepsilon 4$ & 0 \\
\hline
\end{tabular}

The only differences to a European population were observed with the Spanish sample, for the ITGB3 polymorphism $(p=0.0107)$. Furthermore, the exact test of population differentiation revealed significant differences between the Azores and samples from the following nonEuropean populations: the Japanese $(A C E, p=0.0000)$, sub-Saharan Africans ( $L T A, p=0.0039 ; N O S 3, p=0.0000)$ and African-Americans (LTA, $p=0.0001 ;$ PAI1, $p=0.0002$; NOS3, $p=0.0001 ; F G B, p=0.0030)$.

\section{Genotype/phenotype correlations}

The results of the analysis between APOE and PON1 55 genotypes and lipid profile are shown in Table III. A statistically significant difference was observed between LDL-C values in the three APOE genotypes. Individuals with the $\varepsilon 3^{\star} \varepsilon 4$ genotype had significantly higher LDL-C values $(220 \pm 7 \mathrm{mg} / \mathrm{dl})$ than the individuals with the $\varepsilon 3^{*} \varepsilon 3$ $(207 \pm 4 \mathrm{mg} / \mathrm{dl})$ and $\varepsilon 2^{\star} \varepsilon 3(198 \pm 8 \mathrm{mg} / \mathrm{dl})$ genotype. No significant effect of the APOE genotypes on triglycerides, TC and HDL-C levels was detected.

For PON1, individuals with the 55-LL genotype had significantly higher levels of TC $(226 \pm 7 \mathrm{mg} / \mathrm{dl})$ than individuals with the 55-ML genotype $(202 \pm 4 \mathrm{mg} / \mathrm{dl})$. No significant differences were observed between triglycerides, LDL-C and HDL-C levels among PON1 genotypes.

The kernel regression test showed a slight correlation between genotype and blood pressure (both for ACE I/D gene polymorphism and NOS3 894G $>$ T gene polymorphism). $R^{2}$ was 0.0252 (systolic BP) and 0.0259 (diastolic BP) for ACE and 0.0073 (systolic BP) and 0.0147 (diastolic BP) for NOS3. Therefore, the probability of blood pressure depending on $A C E$ genotype is $2.52 \%$ for systolic BP and $2.59 \%$ for diastolic BP. For the NOS3 locus, the probability is $0.73 \%$ and $1.47 \%$ for systolic BP and diastolic BP, respectively.

\section{DISCUSSION}

We have genotyped eight polymorphisms in established susceptibility genes for atherosclerosis in 305 Azorean samples. The genetic profile disclosed was similar to that observed in other European populations, namely on the mainland of Portugal. No over-representation of the respective risk alleles at the loci studied was shown in our sample.

Results from this study indicate that serum total cholesterol is a major risk factor for atherosclerosis in the Azorean population, followed by hypertension and obesity. The BMI value found in this study, although high, has been previously reported for other Portuguese populations (Mendonça et al. 2008). These latter authors, studying a sample from mainland Portugal, found a mean value of BMI $(27.4 \pm 4.1)$ which is very similar to the result obtained for the Azorean sample. Interestingly, the frequency of hypercholesterolemia reported by Mendonça et al. (2008) $(30.3 \%)$ is much lower than the one in the present sample $(63.6 \%)$. The high frequency of hypercholesterolemic individuals in the Azorean population clearly sets the background for an increased pre-disposition for atherosclerosis. Since we failed to detect any increased frequency of the risk alleles in the loci putatively associated with serum cholesterol compared with the Portuguese population, the genetic basis for the observed tendency for hypercholesterolemia remains to be identified.

Table III. Plasma lipid profile according to APOE and PON1 genotypes more represented in Azores population (mean \pm SE). ${ }^{\mathrm{a}}$

\begin{tabular}{|c|c|c|c|c|c|c|c|c|}
\hline \multirow[b]{2}{*}{ Variable } & \multicolumn{3}{|c|}{ APOE genotypes } & \multicolumn{3}{|c|}{ PON1 genotypes } & \multirow[b]{2}{*}{ Multiple comparison } & \multirow[b]{2}{*}{$p$-value } \\
\hline & $\begin{array}{c}\varepsilon 2^{*} \varepsilon 3 \\
(n=36)\end{array}$ & $\begin{array}{c}\varepsilon 3^{*} \varepsilon 3 \\
(n=180)\end{array}$ & $\begin{array}{c}\varepsilon 3^{\star} \varepsilon 4 \\
(n=46) \\
\end{array}$ & $\begin{array}{c}\mathrm{MM} \\
(n=67)\end{array}$ & $\begin{array}{c}\text { ML } \\
(n=156)\end{array}$ & $\begin{array}{c}\mathrm{LL} \\
(n=46)\end{array}$ & & \\
\hline $\mathrm{CT}(\mathrm{mg} / \mathrm{dl})$ & $198 \pm 8$ & $207 \pm 4$ & $220 \pm 7$ & $209 \pm 6$ & $202 \pm 4$ & $226 \pm 7$ & $\mathrm{ML} \neq \mathrm{LL}$ & 0.008 \\
\hline LDL-C (mg/dl) & $117 \pm 6$ & $126 \pm 2$ & $142 \pm 5$ & $133 \pm 4$ & $123 \pm 3$ & $135 \pm 5$ & $\begin{array}{l}\varepsilon 2^{\star} \varepsilon 3 \neq \varepsilon 3^{\star} \varepsilon 4 \\
\varepsilon 3^{\star} \varepsilon 3 \neq \varepsilon 3^{\star} \varepsilon 4\end{array}$ & $\begin{array}{l}0.011 \\
0.035\end{array}$ \\
\hline HDL-C (mg/dl) & $57 \pm 3$ & $57 \pm 1$ & $53 \pm 2$ & $54 \pm 2$ & $56 \pm 1$ & $57 \pm 2$ & & ns \\
\hline $\mathrm{TG}(\mathrm{mg} / \mathrm{dl})$ & $119 \pm 11$ & $155 \pm 5$ & $135 \pm 9$ & $122 \pm 8$ & $121 \pm 5$ & $121 \pm 9$ & & ns \\
\hline
\end{tabular}

CT, total cholesterol; LDL-C, low-density lipoprotein cholesterol; HDL-C, high- density lipoprotein cholesterol; TG, triglycerides; $\neq$, two groups are different; Adjustments for multiple comparisons: Bonferroni; ns, non-significant ( $p>0.05) .{ }^{\text {a }}$ Concentrations adjusted for age, sex and BMI. 
It is noteworthy that the frequency of family history of infarction reported in Mendonça et al. (2008) is almost half the value $(17.4 \%)$ presented in this work. The presence of a higher familial aggregation for infarction in the Azorean population could either reflect the shared environmental factors or variation in loci other than those analysed in this study. The possibility that familial forms of hypercholesterolemia could explain, at least in part, some of this aggregation is currently being investigated.

Numerous studies (see among others, Sing and Davignon 1985; Hanis et al. 1991; Howard et al. 1998) have previously reported associations between variation at the APOE locus and cholesterolemia, which we were able to confirm in the present study. Thus, the $\epsilon 2$ allele lowers the concentration of TC and LDL-C levels and the $\epsilon 4$ allele raises them. The $\epsilon 2$ cholesterol-lowering effect is 2-3-times that of $\epsilon 4$ cholesterol-raising effect. In several studies, $\epsilon 4$ carriers have been associated with an increased risk of coronary heart disease (Eichner et al. 2002). On the other hand, $\epsilon 2$ carriage may confer cardioprotective effects (Bennet et al. 2007). A correlation has previously been reported between blood pressure and variation at ACE (Henskens et al. 2003; Di Pasquale et al. 2004) and NOS3 (Jia et al. 2003; Sawada et al. 2008); in accordance with these findings a slight correlation between genotypes in the previous loci and BP was reported in the Azorean correlation.

In conclusion, the fact that no over-representation of the respective risk alleles at the loci studied was evidenced in our sample does not preclude the possibility that variation at other loci could influence the pre-disposition for atherosclerosis in the Azorean population. Given the fact that AT is a multi-factoral disorder, with several genetic and environmental factors involved, we have to consider the possibility that an important non-genetic influence is playing a role in the high cholesterolemia present in the Azorean population. Diet is the most important life-style risk factor for dyslipidemia; studies to evaluate the dietary characteristics of this population are currently ongoing.

\section{ACKNOWLEDGEMENTS}

The authors are grateful to Jorge Morgado (Health Centre of Nordeste), Jorge Oliveira (Health Centre of Povoação), Emiliana Dias (Health Centre of Sta Cruz das Flores), Maria João Carreiro (Health Centre of Vila Franca do Campo), Joaquim Ferreira da Silva (Health Centre of Sta Cruz da Graciosa), José Aires Raposo (Health Centre of Ribeira Grande) and Helena Gago da Câmara (Atlantilab laboratory) and to all the technical staff for their support in blood collection and in the determination of serum lipid profile.

Declaration of interest: This work was supported by the project 'Search for nuclear and mitochondrial biomarkers of atherosclerosis in isolated populations from Azores Islands' reference M2.1.2/F/009/2007, funded by the Regional Government of the Azores and 'High Prevalence pathologies in the Azores: Genomic and biochemical markers', funded by DRCT, in the scope of the
Biotechnology and Biomedicine Institute of the Azores (IBBA) (M2.1.2/I/026/2008). T.C. [SFRH/BPD/38659/2007] and C.B. [SFRH/BPD/63121/2009] are recipients of Postdoctoral grants from Fundação para a Ciência e a Tecnologia. N.K. [M3.1.3/F/004/2009] is a recipient of a Post-doctoral grant from the Secretaria Regional da Ciência, Tecnologia e Equipamentos. R.F. is a $\mathrm{PhD}$ grantee of Fundação para a Ciência e a Tecnologia [SFRH/BD/34322/2007]. The authors report no conflicts of interest. The authors alone are responsible for the content and writing of the paper.

\section{REFERENCES}

Addinsoft. 2010. XLSTAT 2010. Available online at http://www.xlstat. com, accessed 30 September 2010.

Bennet AM, Di Angelantonio E, Ye Z, Wensley F, Dahlin A, Ahlbom A, Keavney B, Collins R, Wiman B, de Faire U, Danesh J. 2007. Association of apolipoprotein E genotypes with lipid levels and coronary risk. JAMA 298:1300-1311.

Bettencourt C, Montiel R, Santos C, Pavão ML, Viegas-Crespo AM, Lopes PA, Lima M. 2006. Polymorphism of the APOE locus in the Azores Islands (Portugal). Hum Biol 78:509-512.

Bruges-Armas J, Lima C, Peixoto MJ, Santos P, Mendonça D, da Silva BM, Herrero-Beaumont G, Calin A. 2002. Prevalence of spondyloarthritis in Terceira, Azores: a population based study. Ann Rheum Dis 61:551-553.

Burman D, Mente A, Hegele RA, Islam S, Yusuf S, Anand SS. 2009. Relationship of the ApoE polymorphism to plasma lipid traits among South Asians, Chinese, and Europeans living in Canada. Atherosclerosis 203:192-200.

Casas JP, Bautista LE, Humphries SE, Hingorani AD. 2004. Endothelial nitric oxide synthase genotype and ischemic heart disease: metaanalysis of 26 studies involving 23028 subjects. Circulation 109: $1359-1365$.

Chobanian AV, Bakris GL, Black HR, Cushman WC, Green LA, Izzo JL Jr, Jones DW, Materson BJ, Oparil S, Wright JT Jr, Roccella EJ. 2003. National Heart, Lung, and Blood Institute Joint National Committee on Prevention, Detection, Evaluation, and Treatment of High Blood Pressure; National High Blood Pressure Education Program Coordinating Committee. The Seventh Report of the Joint National Committee on Prevention, Detection, Evaluation, and Treatment of High Blood Pressure: the JNC 7 report. JAMA 289: $2560-2572$.

David D, Ribeiro S, Ferrão L, Gago T, Crespo F. 2004. Molecular basis of inherited antithrombin deficiency in Portuguese families: identification of genetic alterations and screening for additional thrombotic risk factors. Am J Hematol 76:163-171.

Di Pasquale P, Cannizzaro S, Paterna S. 2004. Does angiotensinconverting enzyme gene polymorphism affect blood pressure? Findings after 6 years of follow-up in healthy subjects. Eur J Heart Fail 6:11-16.

Direcção-Geral da Saúde, editor. 2009. Elementos estatísticos, Informação Geral - Saúde/ 2007. Lisbon [ISSN 0872-1114].

Eichner JE, Dunn ST, Perveen G, Apolipoprotein E, Thompson DM, Stewart KE, Stroehla BC. 2002. polymorphism and cardiovascular disease: a HuGE review. Am J Epidemiol 155:487-495.

Excoffier L, Laval G, Schneider S. 2005. Arlequin ver. 3.0: An integrated software package for population genetics data analysis. Evolutionary Bioinformatics Online 1:147-150.

Expert Panel on Detection, Evaluation and Treatment of High Blood Cholesterol in Adults. 2001. Executive Summary of the Third REFERENCES Report of the National Cholesterol Education Program (NCEP) Expert Panel on Detection Evaluation and Treatment of High Blood Cholesterol in Adults (Adult Treatment Panel III). JAMA 285:2486-2497. 
Ferrer-Antunes C, de Maat MP, Palmeiro A, Pimentel J, Fernandes V. 1998. Association between polymorphisms in the fibrinogen alphaand beta-genes on the post-trauma fibrinogen increase. Thromb Res 92:207-212.

Friedewald WT, Levy RI, Fredrickson DS. 1972. Estimation of the concentration of low-density lipoprotein cholesterol in plasma, without use of the preparative ultracentrifuge. Clin Chem 18: 499-502.

Garcés C, López-Simón L, Rubio R, Benavente M, Cano B, Ortega H, de Oya M. 2008. High-density lipoprotein cholesterol and paraoxonase 1 (PON1) genetics and serum PON1 activity in prepubertal children in Spain. Clin Chem Lab Med 46:809-813.

Gialeraki A, Politou M, Rallidis L, Merkouri E, Markatos C, Kremastinos D, Travlou A. 2008. Prevalence of prothrombotic polymorphisms in Greece. Genet Test 12:541-547.

Hanis CL, Hewett-Emmett D, Douglas TC, Bertin TK, Schull WJ. 1991. Effects of the apolipoprotein E polymorphism on levels of lipids, lipoproteins, and apolipoproteins among Mexican-Americans in Starr County, Texas. Arterioscler Thromb 11:62-70.

Henskens LH, Spiering W, Stoffers HE, Soomers FL, Vlietinck RF, de Leeuw PW, Kroon AA. 2003. Effects of ACE I/D and AT1RA1166C polymorphisms on blood pressure in a healthy normotensive primary care population: first results of the Hippocates study. J Hypertens 21:81-86.

Howard BV, Gidding SS, Lui K. 1998. Association of apolipoprotein E phenotype with plasma lipoproteins in African-American and white young adults: the CARDIA Study. Coronary Artery Risk Development in Young Adults. Am J Epidemiol 148:859-868.

INE. 2006. Estimation of resident population 2001 based on provisory results of Census 2006. Portugal: National Institute of Statistics (in Portuguese).

Jia CQ, Zhao ZT, Wang LH, Hao FR, Feng YQ, Wang SM, Xu XF, Jia CX. 2003. Effects of G894T mutation in the endothelial nitric oxide synthase gene on blood pressure. Zhonghua Liu Xing Bing Xue Za Zhi 24:36-39.

Knowles JW, Wang H, Itakura H, Southwick A, Myers RM, Iribarren C, Fortmann SP, Go AS, Quertermous T, Hlatky MA. 2007. Association of polymorphisms in platelet and haemostasis system genes with acute myocardial infarction. Am Heart J 154:1052-1058.

Lima M, Costa MC, Montiel R, Ferro A, Santos C, Silva C, Bettencourt C, Sousa A, Sequeiros J, Coutinho P, Maciel P. 2005. Population Genetics of wild-type CAG repeats in the Machado-Joseph disease (MJD) gene in Portugal. Hum Hered 60:156-163.

Mackness MI, Mackness B, Durrington PN, Fogelman AM, Berliner J, Lusis AJ, Navab M, Shih D, Fonarow GC. 1998. Paraoxonase and coronary heart disease. Curr Opin Lipidol 9:319-324.

Magro F, Dinis-Ribeiro M, Araújo FM, Pereira P, Fraga MC, Cunha-Ribeiro LM, Tomé-Ribeiro A. 2003. High prevalence of combined thrombophilic abnormalities in patients with inflammatory bowel disease. Eur J Gastroenterol Hepatol 15:1157-1163.

Marian AJ, Brugada R, Kleiman NS. 1996. Platelet glycoprotein IIIa PlA polymorphism and myocardial infarction. N Engl J Med 335: $1071-1072$.

Matos AT. 1989. Origem e reminiscências dos povoadores das ilhas atlânticas. In: Comissão Nacional para as Comemorações dos Descobrimentos Portugueses, editors. Actas do Congresso Internacional Bartolomeu Dias e a Sua Época, Universidade do Porto, Porto. p 241-252.

Medeiros R, Morais A, Vasconcelos A, Costa S, Pinto D, Oliveira J, Lopes C. 2002. Endothelial nitric oxide synthase gene polymorphisms and genetic susceptibility to prostate cancer. Eur J Cancer Prev 11:343-350.

Mendonça L. 1996. Azores History - General Vision (centuries XV to XIX). Ponta Delgada, Azores. Portugal: Centre of Tecnological Suport to Education (in Portuguese).

Mendonça MI, Dos Reis RP, Freitas AI, Sousa AC, Pereira A, Faria P, Gomes S, Silva B, Santos N, Serrão M, Ornelas I, Freitas S, Araújo JJ, Brehm A, Cardoso AA. 2008. Human paraoxonase gene polymorphisms and coronary artery disease risk. Rev Port Cardiol 27:1539-1555.

Montiel R, Bettencourt C, Silva C, Santos C, Prata MJ, Lima M. 2005. Analysis of $\mathrm{Y}$-chromosome variability and its comparison with mtDNA variability reveals different demographic histories between Islands in the Azores Archipelago. Ann Hum Genet 69:1-10.

Nei M. 1978. Estimation of average heterozygosity and genetic distance from a small number of individuals. Genetics 89:583-590.

Onalan O, Balta G, Oto A, Kabakci G, Tokgozoglu L, Aytemir K, Altay C, Gurgey A, Nazli N. 2008. Plasminogen activator inhibitor-1 4G4G genotype is associated with myocardial infarction but not with stable coronary artery disease. J Thromb Thrombolysis 26:211-217.

Renner W, Cichocki L, Forjanics A, Köppel H, Gasser R, Pilger E. 2002. G-455A. polymorphism of the fibrinogen beta gene and deep vein thrombosis. Eur J Clin Invest 32:755-758.

Ridker PM, Hennekens CH, Schmitz C, Stampfer MJ, Lindpaintner K. 1997. PIA1/A2 polymorphism of platelet glycoprotein IIIa and risks of myocardial infarction stroke, and venous thrombosis. Lancet 349: 385-388.

Rigat B, Hubert C, Alhenc-Gelas F, Cambien F, Corvol P, Soubrier F. 1990. An insertion/deletion polymorphism in the angiotensin I-converting enzyme gene accounting for half the variance of serum enzyme levels. J Clin Invest 86:1343-1346.

Rodrigues MO, Fonseca A, Matias-Dias C, Albergaria I, Martins G, Alpendre ML, do Martins MC. 2005. APOE genotypes and dyslipidemias in a sample of the Portuguese population. Clin Chem Lab Med 43:907-912.

Roy H, Bhardwaj S, Yla-Herttuala S. 2009. Molecular genetics of atherosclerosis. Hum Genet 125:467-491.

Sabbagh AS, Otrock ZK, Mahfoud ZR, Zaatari GS, Mahfouz RAR. 2007. Angiotensin-converting enzyme gene polymorphism and allele frequencies in the Lebanese population: prevalence and review of the literature. Mol Biol Rep 34:47-52.

Salonen JT, Malin R, Tuomainen TP, Nyyssonen K, Lakka TA, Lehtimaki T. 1999. Polymorphism in high-density lipoprotein paraoxonase gene and risk of acute myocardial infarction in men: prospective nested case-control study. Br Med J 319:487-489.

Samani NJ, Thompson JR, O’Toole L, Channer K, Woods KL. 1996. A meta-analysis of the association of the deletion allele of the angiotensin converting enzyme gene with myocardial infarction. Circulation 94:708-712.

Santos C, Alvarez L, Aluja MP, Bruges-Armas J, Lima M. 2009. Genetic structure of the Azores Islands: a study using 15 autosomal short tandem repeat loci. Coll Antropol 33:991-999.

Santos C, Lima M, Montiel R, Anglés N, Pires L, Abade A, Aluja MP. 2003. Genetic structure and origins of peopling in the Azores Islands (Portugal): the view from mtDNA. Ann Hum Genet 67:433-456.

Sawada T, Kishimoto T, Osaki Y, Okamoto M, Tahara A, Kaetu A, Kurosawa Y, Kotani K. 2008. Relation of the Glu298Asp polymorphism of the nitric oxide synthase gene to hypertension and serum cholesterol in Japanese workers. Prev Med 47:167-171.

Schreyer SA, Vick CM, LeBoeuf RC. 2002. Loss of lymphotoxin-alpha but not tumor necrosis factor-alpha reduces atherosclerosis in mice. J Biol Chem 277:12364-12368.

Sing CF, Davignon J. 1985. Role of the apolipoprotein E polymorphism in determining normal plasma lipid and lipoprotein variation. Am J Hum Genet 37:268-285.

Trompet S, de Craen AJM, Slagboom P, Shepherd J, Blauw GJ, Murphy MB, Bollen ELEM, Buckley BM, Ford I, Gawh A, Macfarlane PW, Packard CJ, Stott DJ, Westendorp RGJ, Jukema JW, on behalf of the PROSPER Group. 2008. Lymphotoxin-alpha C804A polymorphism is a risk factor for stroke. The PROSPER study. Exp Gerontol 43: 801-805.

Zhang Y, Zheng F, Du H, Krepinsky JC, Segbo JA, Zhou X. 2006. Detecting the polymorphisms of paraoxonase $(\mathrm{PON})$ cluster in Chinese Han population based on a rapid method. Clin Chim Acta 365:98-103. 